6. Exner, D.N. 1997. Productivity and profitability of strip intercropping systems as implemented by agronomists and farmers. Ph.D. diss. Iowa State Univ., Ames.

7. Francis, C.A., A. Jones, K. Crookston, K. Wittler, and S. Goodman. 1986. Strip cropping corn and grain legumes: A review. Amer. J. Alternative Agric. 1(4):159-164.

8. Gilley, J.E., L.A. Kramer, R.M. Cruse, and A. Hull. 1997. Sediment movement within a strip intercropping system. J. Soil and Water Conservation 52(6):443-447.

9. Hien, V., D. Kabore, S. Youl, and J. Lowenberg-DeBoer. 1993. Stochastic dominance analysis of on-farm-trial data: The case of the Food Crops Fer- tilizer Project, Burkina Faso, 1889 to 1991. Staff paper 93-19. Department of Agricultural Economics, Purdue University, West Lafayette.

10. Norman, D.W. 1974. Rationalising mixed cropping under indigenous conditions: The example of northern Nigeria. J. Dev. Stud. 11(1): 3-21.

11. Pendleton, J.W., C.D. Bolen, and R. D. Seif. 1963. Alternating strips of corn and soybeans vs. solid plantings. Agronomy J. 55:293-295.

12. Shen, L. 1984. Yield response of corn and soybean strip intercropping in different row directions. M.S. thesis. Iowa State University, Ames.

13. Steel, R.G.D., and J.H. Torrie. 1980. Principles and Procedures of Statis- tics: A Biometrical Approach. 2nd ed. McGraw-Hill, NY.

14. Weber, E. 1993. Narrow strip intercropping: Creating wider windows of opportunity. Leopold Center for Sustainable Agriculture, Ames, IA. Leopold Letter 5(3):4-6.

15. West, T.D., and D.R. Griffith. 1992. Effect of strip intercropping corn and soybean on yield and profit. J. Production Agric. 5(1):107-110.

16. Willey, R.W. 1985. Evaluation and presentation of intercropping advantages. Experimental Agric. 21:119133.

17. Wittler, G.K. 1986. Summary of Strip Cropping. Parkland College, Champaign, IL.

\title{
INSTITUTE NEWS
}

\section{New Study Identifies Success Strategies for Natural Foods Market}

The natural foods market is growing exponentially, but can only reach its full potential if it makes strong connections with the mass market foods industry, according to a new report from the Henry A. Wallace Institute for Alternative Agriculture entitled The Natural Foods Market: A National Survey of Strategies for Growth. The mass market foods industry, in turn, must discover how it can integrate natural foods into existing operations, the report concludes.

The report reveals the results of the Institute's 1998 Natural Foods Market Survey, which interviewed about 300 food industry businesses, including farmers, manufacturers, wholesalers, and retail supermarkets. The report analyzes current trends and major obstacles, as well as successful business strategies in the natural foods market.

The retail market for natural foods is growing at five times the rate of the total retail food market. "The natural foods market has the potential to make a positive impact on the environment and consumers' health and well-being," said Nessa Richman, the report's author, "but growing the market smart is just as important as growing the market fast in the long term."

According to the report, three major obstacles to success for the natural foods market are: no widely accepted standards for defining and producing natural foods; natural foods and mass market foods companies view the natural foods market and conduct business in critically different ways; and many natural foods and mass market foods businesses do not have the information they need to market and price natural foods.

While some of these obstacles will fade as the natural foods market matures, several public policy actions could enhance the market's potential benefit to private and public interests. They include developing commonly recognized standards for natural foods, collecting market and price information for natural foods, and creating generic marketing channels for natural foods.
Several strategies employed by natural and mass market foods companies are leading to success in the natural foods market for some market segments, among them developing a natural foods label, hiring special staff for natural foods, and increasing the scale of their natural foods operations, according to the report.

With the goal of helping the natural foods market reach its full potential, the report makes recommendations for government agencies, trade organizations, research and education institutions, and industry members.

The Natural Foods Market is available for $\$ 150$ (non-profit rate available upon request) from the Wallace Institute, 9200 Edmonston Road, \#117, Greenbelt, MD 20770; (301) 441-8777; an Executive Summary is available at no cost.

\section{Organic Crops Can Be As, or More, Profitable As Conventional}

Organic cropping systems in the midwestern United States can be as profitable, or even more profitable, than most con-

Continued on page 96 